\title{
Structural Inversion Magnitude and its Impacts on the Hydrocarbon Accumulation
}

\section{sciendo}

\author{
Mohamed G. El-Behirya, Adly H. D. El-Nikhelyb, Bassem M. El Sayed ${ }^{c}$ \\ aGeophysics Department, Faculty of Science, Cairo University, Giza, Egypt \\ ${ }^{\mathrm{b}}$ Geophysics Department, Faculty of Science, Alexandria University, Alexandria, Egypt \\ 'Abu Qir Petroleum Co., Alexandria, Egypt
}

\section{DOI: 10.2478/pjg-2019-0006}

\section{Abstract:}

West Wadi El-Rayan is located in the Western Desert at about $140 \mathrm{~km} \mathrm{SE}$ of Cairo. Also, it lies between Gindi basin to the east and Abu Gharadig basin to the west. In order to construct a 3D structural model and to delineate the subsurface structure styles of the area, seismic structural interpretation and structural restoration are used. The structural geometry within the area is inverted half-graben, since the area was controlled by reactivation of older faults. The magnitude of the inversion-related shortening in the study area was estimated and was suggested to be strong. The result of the strong inversion magnitude occurred toward northeast of the study area can be concluded that, the area suffered shortening and part of the Jurassic / Early Cretaceous normal faults are reactivated as reverse faults. Also the cap, the main reservoirs and the source rock sections are brought to the surface and thus breached, as well any previous mature source rock becoming non-generative where the dry wells are located. However, any less severe inversion structure in this case where producing wells are located that remain buried and will have a better chance or preserving the structure geometry and therefore top and lateral seal.

Keywords: Inversion magnitude, structural restoration, 3D seismic Interpretation, Western Desert

\subsection{Introduction:}

West Wadi El-Rayan Concession (WWER) is located in the Western Desert at about $140 \mathrm{~km}$ South West of Cairo and $65 \mathrm{~km}$ South West of El-Fayoum. Furthermore, the study area lies between latitudes $29^{\circ} 33^{`}-29^{\circ} 48^{`} \mathrm{~N}$ and longitudes $29^{\circ} 56^{`}-30^{\circ} 10^{`} \mathrm{E}$, (Figure 1)[1]. The first oil discovery well in WWER Concession is WWER-2X well and was drilled in March, 2009. WWER Concession had been operated by Edison International Company. The main objective of this exploratory well was the Upper Bahariya formation.

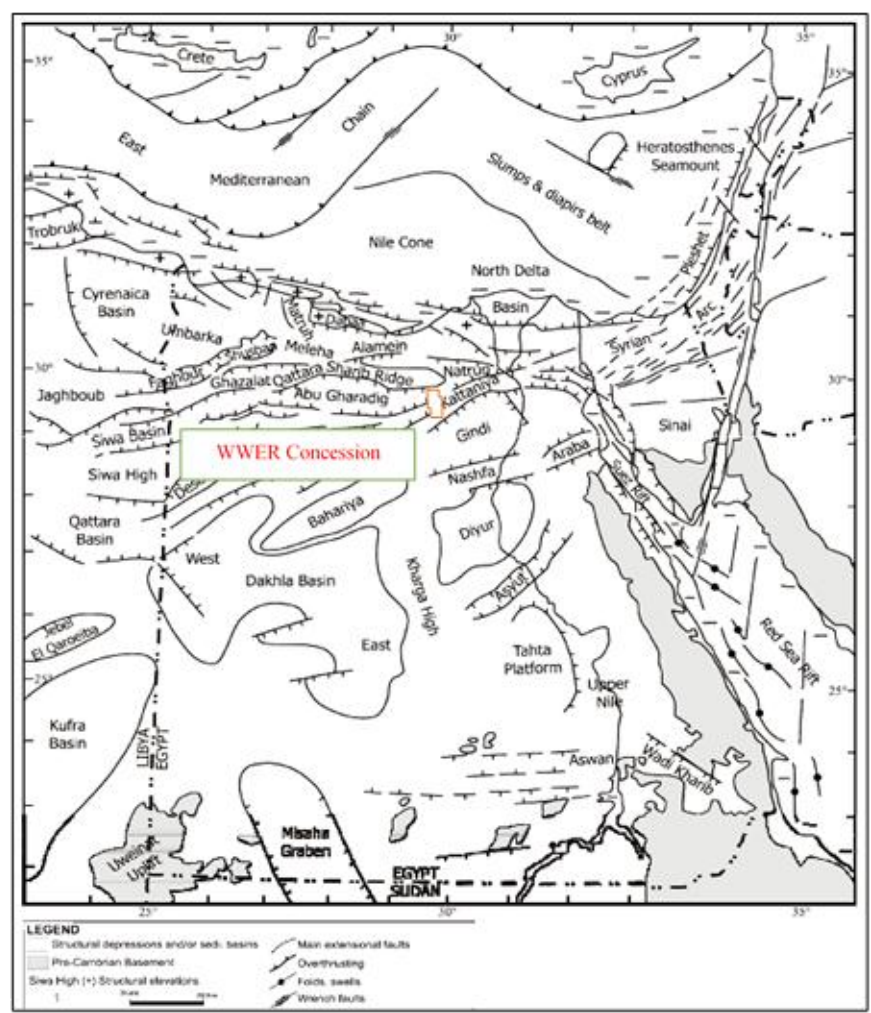

Figure 1: Map of Egypt and southeast Mediterranean Sea showing main structural elements and sedimentary basins [1].

Horizon interpretations in the WWER study area began on vertical sections at the well tie location and extended outward. Furthermore, horizons Interpretation became easier due to the fact that the seismic data was Pre-Stack depth migrated, in another meaning horizons interpretation process took place in the geological (i.e. depth) domain.

Fault interpretations are important components in the prediction of hydrocarbon reservoir volumes in structural traps, and in forecasting the integrity and performance for structurally complex reservoirs $[2,3$, and 4$]$.

The main objective of the present study were aims to understand the structure geometry affected and address the challenges of structural inversion within the study area. Furthermore, this study will help in understating why we have dry wells at higher structural position while the producing wells at lower structural position in the area.

\subsection{Structural and Geological Setting:}

West Wadi El-Rayan Concession (WWER) in the Khattaniya high lies in a transition area between two major prolific sedimentary basins in the Western Desert of Egypt. These are Gindi basin (Eocene) on the eastern side and Abu Gharadig basin (Mesozoic) on the western side. (Figure 1).

The WWER area has a complex structure, both the well data and seismic interpretation shows that, the Jurassic is characterize d by a half-graben tilted fault blocks trending NE-SW. Rifting and normal faulting continuous into the Early Cretaceous, as indicated by growth normal faults in the Alam El-Bueib Formation.

During late Cretaceous-Early Tertiary the area was affected by a severe tectonic event which was responsible for the onset of the Syrian-Arc NE-SW oriented 
system. As a result of this tectonic event, the main structure located in the central part of the concession was rejuvenated and most of the Upper Cretaceous sedimentary section was eroded.

Due to this event, the Kattaniya basin was created in the Northeastern part of the concession. As a result of late Cretaceous-Early Tertiary tectonic, a series of NE-SW reverse oriented faults and NW-SE normal oriented faults have been created.

\subsection{Stratigraphy}

The stratigraphic succession of northern Egypt (Figure 2) is characterized by several carbonate-clastic alternations. The stratigraphic succession can be subdivided into four major regressive cycles, each terminated by a marine transgression [5].

The earliest cycle consists of the Middle and Late Jurassic nonmarine clastics (Ras Qattara Formation). These nonmarine clastics are overlain by marine Jurassic clastics of Khatatba Formation, followed by shallow marine carbonates of the Masajid Formation that represent the maximum Jurassic transgression.

A major unconformity separates the Masajid Formation from the Alam El Bueib Formation. In the study area The Masajid Formation is entirely eroded or non-deposited on local highs. The second cycle began in the Early Cretaceous with the deposition of the Alam El Bueib that composed of shallow marine clastics and carbonates and ended with the Dahab shale.

The third cycle extends from the middle Albian to the early Tertiary. It begins of the Kharita Formation that represent the initial regressive period of sedimentation. The Bahariya Formation was deposited on a shallow marine shelf during the early Cenomanian. Followed by deposition of Abu Roash A-F members.

The Khoman Formation was deposited above the Abu Roash Formation and this cycle ended by deposition of the Eocene carbonate rocks of the Apollonia Formation.

The uppermost cycle consists of the Dabaa and Moghra marine clastics which are capped by the Marmarica Limestone. The Dabaa Formation was not deposited over local highs and platforms [6].

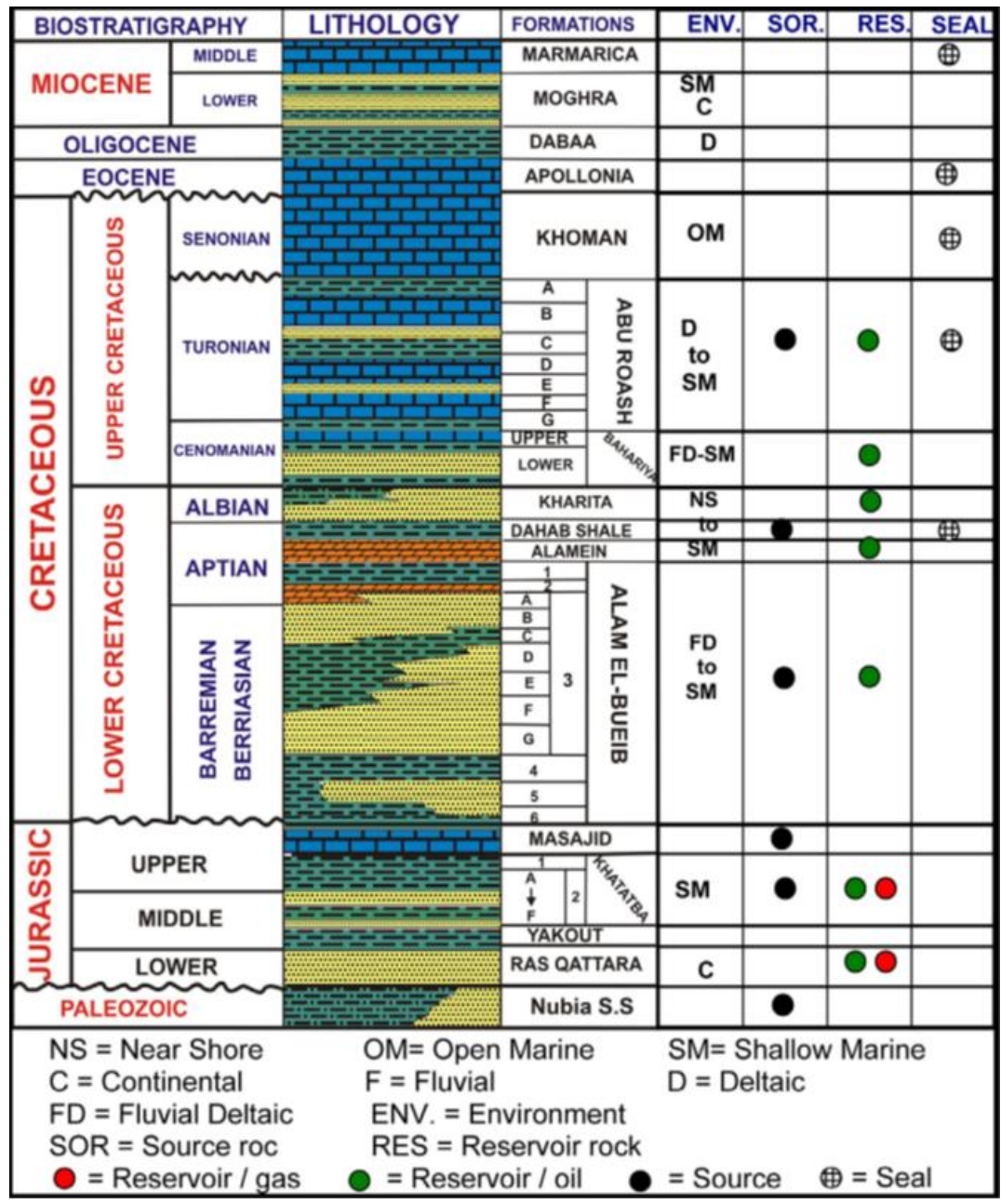

Figure 2: Simplified stratigraphic section of the Western Desert, Egypt [7].

\subsection{Materials and Methods:}

The database of the present work contains 3D seismic data, well-log data, geological and geophysical reports, formation tops and check-shot data. The 3D seismic survey $\left(550 \mathrm{~km}^{2}\right)$ covered WWER area acquired in 2007, the 3D Pre-Stack Time Migration was processed in 2008 and 3D Pre-Stack Depth Migration was processed in 2010. However, 3D PSDM seismic data is used for seismic interpretation, subsurface mapping and structural evaluation with good trusts, Furthermore, the well database includes 4 wells namely WWER 2X, WWER-3, WWER-4 and WD-38 wells for well to seismic tie, stratigraphic and structural correlations, (Figure 3). 


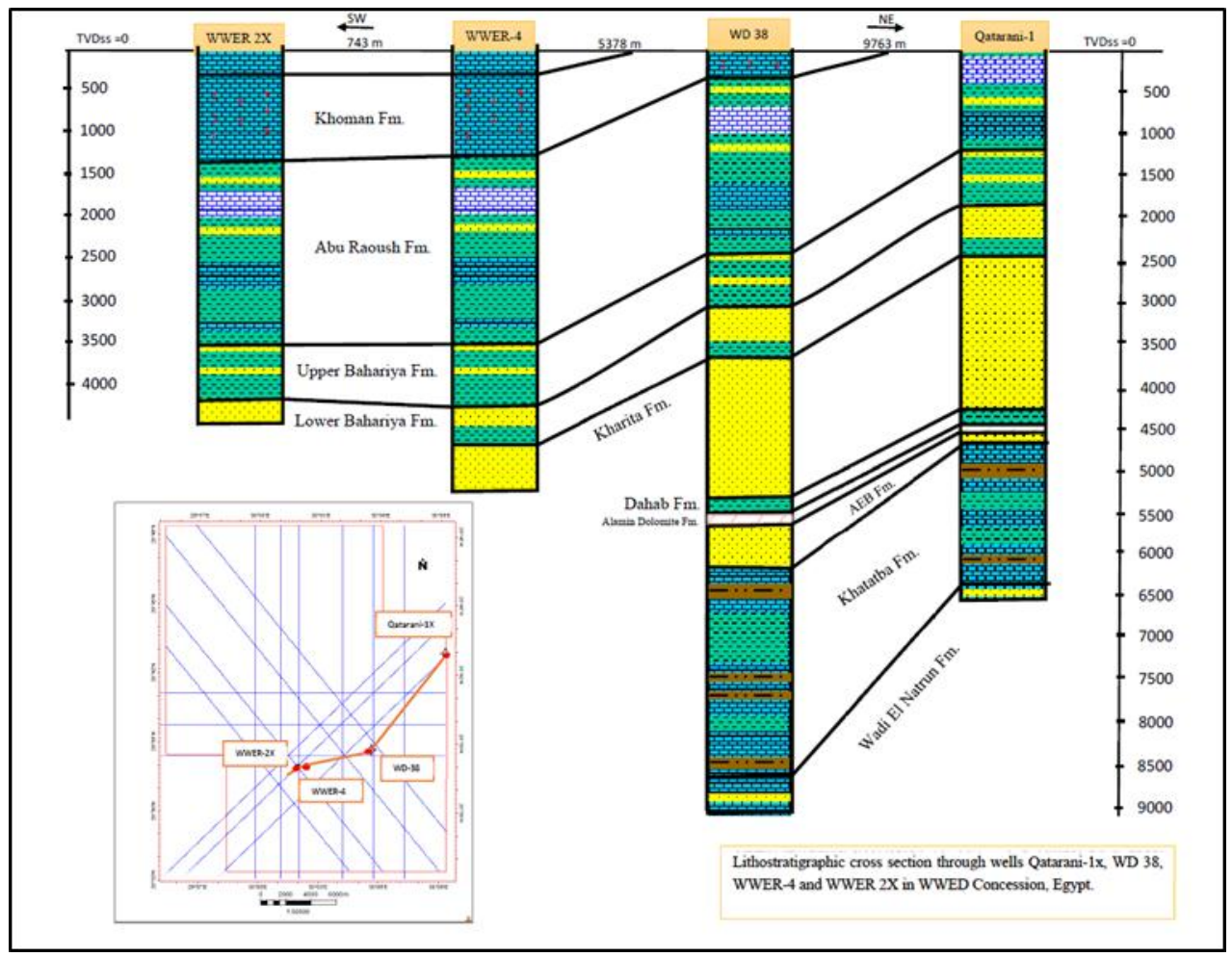

Figure 3: Lithostratigraphic cross section through wells Qatarani-1, WD 38, WWER-4 and WWER 2X.

\subsection{Structural Correlation}

The structural cross section (Figure 3) is leveled to the sea level and passes through the WWER-2X, WWER-4, WD-38, and Qatarani-1 wells. Eight main lithologic units can be identified from the interpretations of these well log data; these are the Appollonia, Khoman, Abu Raosh-D, Upper Bahariya, Kharita, AEB, Khattaba and Wadi El Natrun Formations. Qatarani-1 well [8] is higher in structure followed by WD -38 well in all lithologic units. Generally, the chart exhibits variations in formation thickness from well to another. Also, the deepest well is WD-38 where it reached Khattatba Formation while WWER -2X \& WWER -3 stopped in Baharyia Formation. Appollonia Formation is eroded where well WD-38 is located.

\subsection{Seismic Interpretation}

Seismic interpretation is a key role in extracting geologic information from processed seismic data in order to provide a better understanding of the earth's subsurface, and therefore accurately define the structural and stratigraphic framework of the prospect under investigation [9]. Seismic interpretation in the present study is based on the integration of the seismic data, Well data and regional geological data. It revealed that, the study area has been subjected to inversion tectonics of the Syrian Arc System and hence the area appears to have a positive inverted structure until the Jurassic age. Seismic section (Figure 4) is used to show such inversion structure and its consequences.

The main fault that bounding the study area at the northern side is trending NEE-SWW. It started in the Jurassic age till Cenomanian age and therefore plays a key role in layers thickness and dip variations in the study area (Green). During the Jurassic to the Early Cretaceous age the area has been affected by an extensional subsiding phase that resulted consequently in forming the half-graben tilted northeast-southwest fault blocks (Red). Also, normal northwestsoutheast faults have been formed by the Early Cretaceous (Yellow).

During the Late Cretaceous the tectonic setting of the study area has changed from being an extensional block-fault style to a compressive regime (positive structural inversion formed due to the Syrian arcing system). Accordingly, NE-SW reverse faults have been formed and part of the Jurassic / Early Cretaceous normal faults are reactivated as reverse faults (Black) followed by NW-SE normal oriented faults created during the Eocene age (Blue).

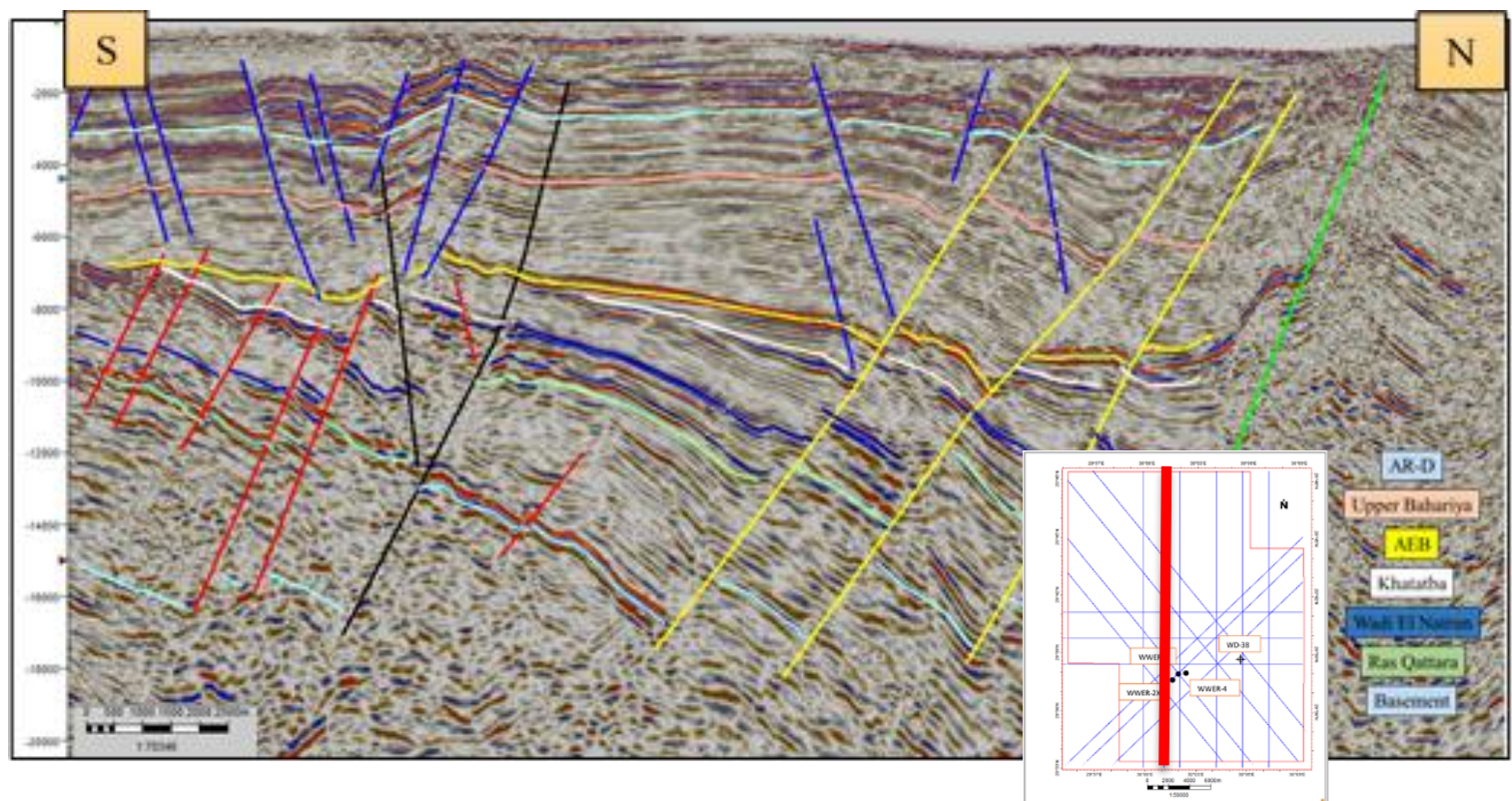


Figure 4: Location map and N-S seismic section showing different fault trends in the study area.

Regional unconformity between Late Jurassic and Early Cretaceous is obvious as indicated from Jurassic sections that shows pinched out, different dipping of reflectors, and thinning toward the South. Also, the area with highest parts of the tilted faulted blocks is eroded while Upper Cretaceous rocks show uniform thickness.

\subsection{Results and Discussion: \\ 4.1. Structural Validation}

Interpreting complex structures that encountered fold, reverse faults and inverted basin are a challenging issue. Such structural validation is essential in order to reduce the uncertainty inherited horizon and fault interpretation. Additionally, to understand and evaluate the geological history within the study area. In the present study, structural restoration / balancing techniques is implemented for structural validation.

In structural restoration, Sequential backstripping removes each sediment layer in sequence. For every sedimentary layers, the steps of structural restoration are, the top sedimentary layer for each stage is removed. Then, the structural deformation that occurred during the corresponding sedimentary interval is restored. Additionally, the compacted section is corrected due to the changes in overburden and deformation. Finally, the restored section is corrected for the tectonic subsidence and for the sea level change that occurred during the corresponding time interval. This process is sequentially repeated for each sediment layer in sequence to be restored.

Many authors have studied the compressional deformation occurring over a wide area of northern Western Desert. Besides, illustrates a restoration model of the basin inversion have presented seismic and outcrop data across northern Egypt to reveal the geometrical differences in the structural style of the inversion [10]. Furthermore, Illustrates a restoration of a simplified true-scale model of the Mubarak inversion and shows restored stages at the presentday. As a result of his interpretation, the magnitude of the inversion on the Mubarak Fault was not enough to remove the net extension of the fault, but the inversion was sufficient to generate over $1.5 \mathrm{~km}$ of vertical relief in the core of the resultant hanging wall anticline.

3D seismic data have been used for structural restorations in order to better understand the tectonic evolution and hence to evaluate structurally the study area [11]. Consequently, the Paleo-tectonic section reflected that the structure of the area is inverted and the timing of inversion took place during Abu Roash and Khoman deposition time.

The main objective of this study is to discuss the impact of inversion on the hydrocarbon potential of the Quran concession area in terms of hydrocarbon generation, migration, and preservation [12]. A regional seismic lines were conducted to show the basin configuration. Moreover, regional Pale-tectonic profiles were achieved in order to present the tectonic history of the kattaniya Basin and El-Gindi Basin. As a result of this study, the structure of the area mainly relates to a Jurassic / Early Cretaceous extensional phase followed by the Cretaceous/ Eocene phase of inversion. In Addition, Basin Inversion effects in negative way in hydrocarbon exploration.

A NW-SE trending seismic section (Figure 5) is selected to show structure restoration. In fact, the NW-SE direction is nearly perpendicular to the prevailed structural orientation. The chosen seismic section shows seven horizons starting from the top Khoman, ARD, Upper Bahariya, AEB, Khatatba and Wadi El Natrun and Ras-Qattara horizons. Additionally, the seismic section revealed a clear positive structural inversion where a reverse slip is clearly indicated on these faults at the level of the Upper Cretaceous rocks whereas at deeper levels (Jurassic) the slip is normal. 

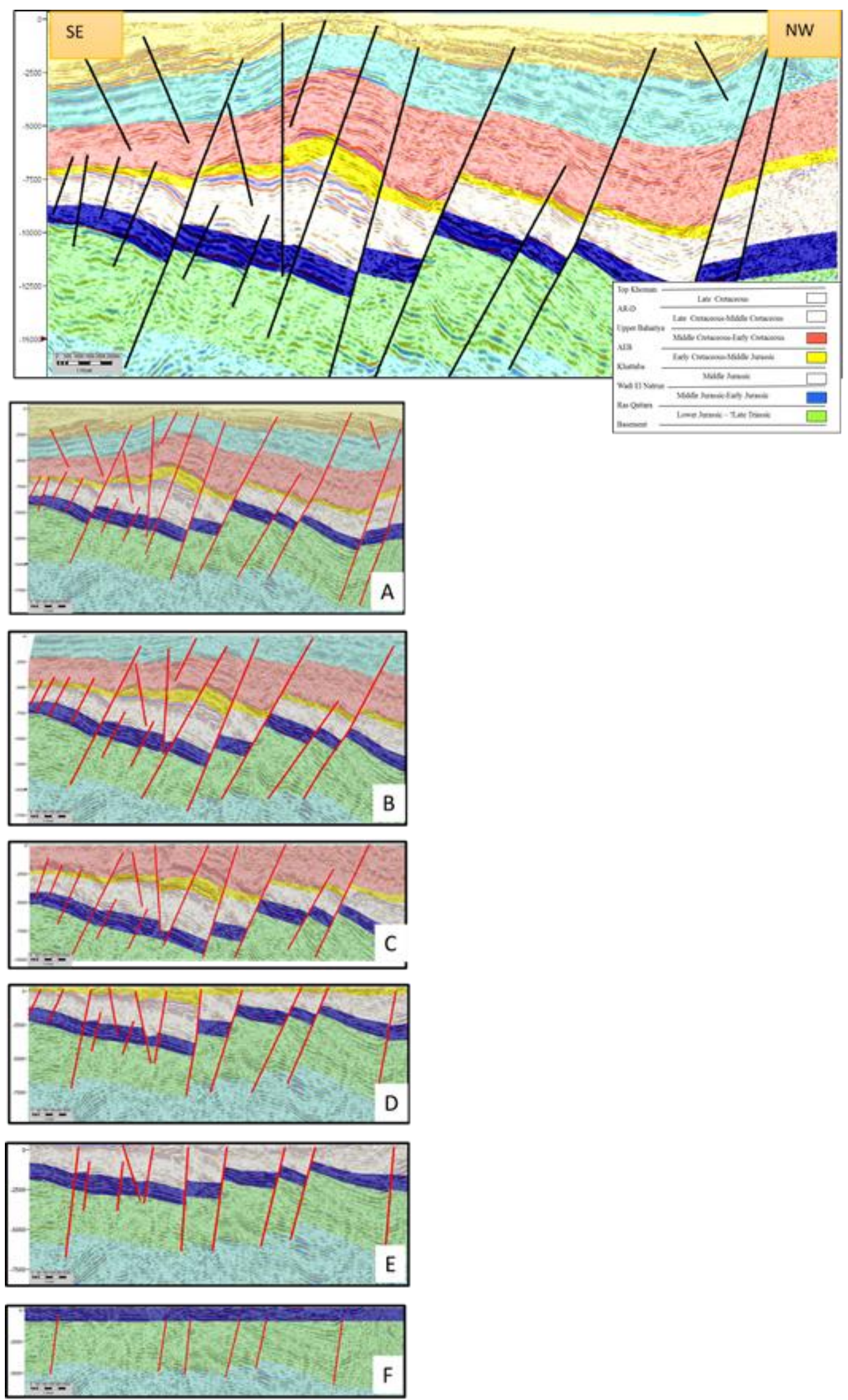

Figure 5: NW-SE seismic section represents the present structure geometry of the study area.

A- $\quad$ Restored section in Khoman time.

B- $\quad$ Restored section in AR-D time.

C- $\quad$ Restored section in Bahariya time.

D- $\quad$ Restored section in AEB time.

E- $\quad$ Restored section in Khatatba time.

F- Restored section in Wadi El Natrun time.

Structural restoration is achieved sequentially, where the Khoman horizon is back stripped. Fault displacements in the Khoman horizon are removed in the reverse order that faulting was thought to have occurred so that the latest formed faults are restored first. After the effects of faulting are accounted for, 
folding deformation is removed by unfolding the Khoman to horizontal. Once the Khoman horizon is back stripped, the remaining horizons are modified for the effects of decompaction and isostatic adjustment (Figure 5-A). The restored section shows positive structural inversion in which some of the NESW Jurassic faults were inverted and NW-SE Cretaceous normal faults, thus the study area is suggested to be inverted structurally at Khoman Time.

Followed by Fault displacement and folding deformation is removed in AR-D horizon, then back stripping was achieved in AR-D horizon (Figure 5-B). The restored section showed a NW-SE Cretaceous normal faults, these faults dissect the post-rift rocks mainly and die out downward within the lower part of the Kharita and/or the upper part of the Alam El Bueib (AEB) Formation, and NE-SW Jurassic normal faults.

In the same way, back stripped is achieved in Upper Bahariya and AEB horizons (Figure 5 - C \& D respectively). The restored section shows NW-SE Cretaceous normal faults, and NE-SW Jurassic normal faults. Regional unconformity between Late Jurassic and Early Cretaceous is obvious and indicated from Jurassic sections that show pinched out, different dipping of reflectors, and thinning toward the south. Also, the higher parts of the tilted faulted block area are eroded.

Finally, the affected faulting displacements are removed and back stripped is achieved in Khatatba and Wadi El Natrun horizons to show the geometry at the end of the deposition (Figure 5- E \& F respectively). The restored sections show a half-graben tilted fault blocks trending NE-SW Jurassic normal faults. It can be emphasized that the final restored section provides confidence in the present day interpretation of the structural framework and understanding of the prevailed geological evolution.

\subsection{Structural Depth Maps}

Wadi El Natrun Formation structure contour map (Figure 6) that represent lower Jurassic, The surface is deformed by NE-SW, NW-SE and ENE-WSW faults; which took place during rifting phases of the late Jurassic and early Cretaceous times that bounded by a major NE-SW normal fault positioned to the north of the studied WWER area.

Alam El Buieb "AEB" Formation structure contour map (Figure 6) represents early Cretaceous time. This structure contour map suggests anticline trending NW-SE direction and was interpreted as inversion related asymmetrical fold bounded by a major NE-SW normal fault lies to the north of WWER area. Also, it showed that AEB was affected by two main normal faults trending NW-SE and ENE-WSW and a NE-SW as a reverse fault. These faults are inverted during the compression phase of the Late Cretaceous.

Bahariya Formation structure contour map (Figure 6) represents middle Cretaceous time and suggests NW-SE trending anticline that was interpreted as inversion related asymmetrical fold bounding by a major NE-SW normal fault lies to the north of WWER area. Also, it showed that Bahariya Formation was affected by two main normal faults trending NW-SE and ENE-WSW and a NE-SW as a reverse fault. These faults are inverted during the compression phase of the Late Cretaceous. 

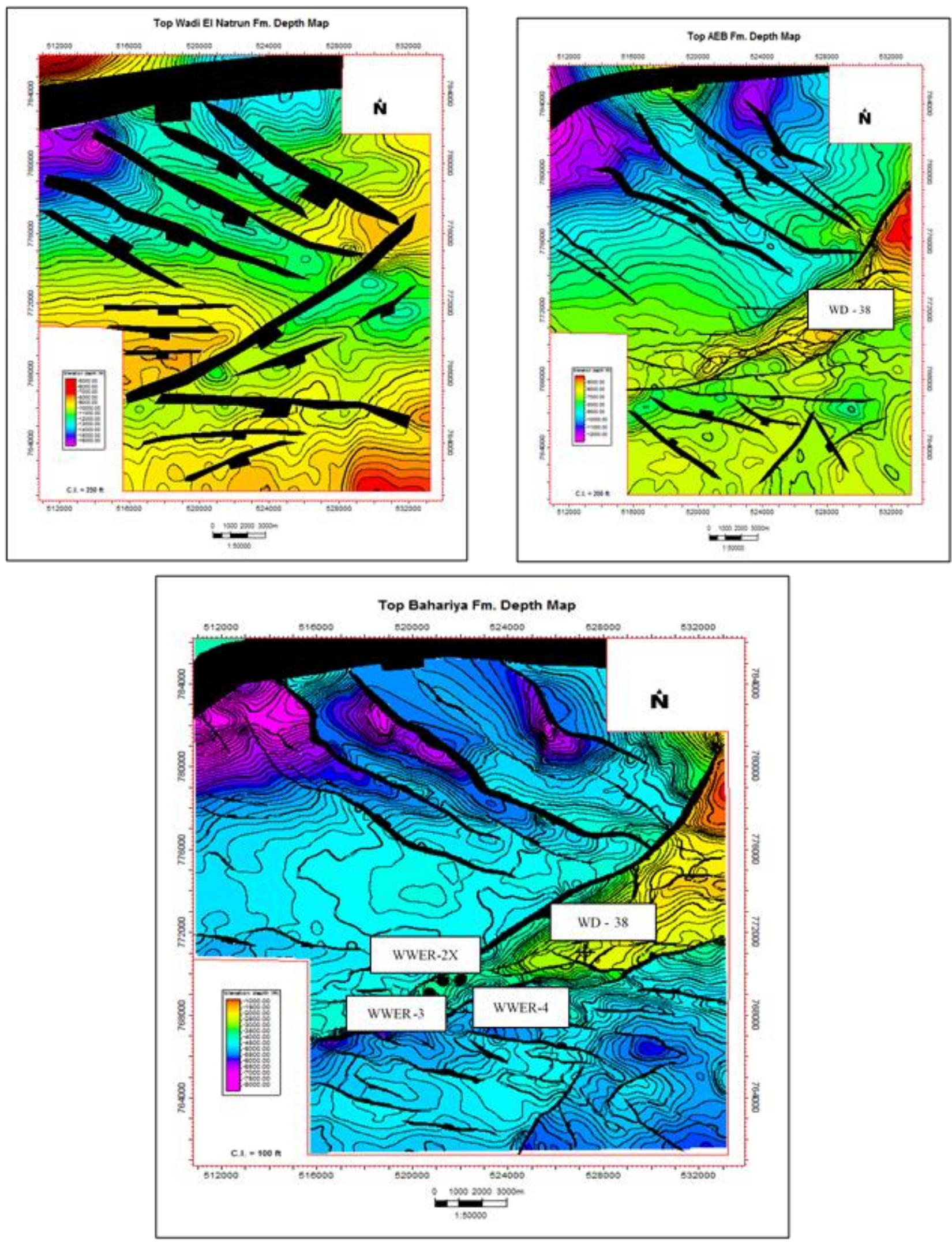

Figure 6: Depth Maps showing Wadi El Natrun, Alam El Bueib and Bahariya Formations.

Qatarani-1 well is located in a higher structural position than WD-38 well, although the two wells were plugged and abandon (P \& A) as a dry hole at Upper Bahariya Level, while WWER-4 and WWER-2X wells are producing from Upper Bahariya Level.

The magnitude of inversion increase towards northeast where strong inversion occurred at Qatarani-1 well, consequently this area suffered shortening and part of the Jurassic / Early Cretaceous normal faults are reactivated as reverse faults. In addition, the cap, the main reservoirs and the source rock sections brought to the surface and thus breached, as well any previous mature source rock becomes non-generative. However, any less severe inversion structure in this case where WWER 2X, WWER-3 and WWER-4 wells are located ( those wells are produced from upper Bahariya fm.) that remained buried by the post Eocene section will have a better chance or preserving the structure geometry and therefore top and lateral seal.

\subsection{Conclusions:}

Detailed subsurface structural interpretation in the study area indicated that, the main fault that bounding the study area at the northern side is trending NEE-SWW. It started in the Jurassic age till Cenomanian age and therefore plays a key role in layers thickness and dip variations in the area. During the 
Jurassic to the Early Cretaceous age the area has been affected by an extensional subsiding phase that resulted consequently in forming the half-graben tilted northeast-southwest fault blocks. In addition, normal northwest-southeast faults have been formed by the Early Cretaceous.

During the Late Cretaceous the tectonic setting of the study area has changed from being an extensional block-fault style to a compressive regime (positive structural inversion formed due to the Syrian arcing system). Accordingly, NE-SW reverse faults have been formed and part of the Jurassic / Early Cretaceous normal faults are reactivated as reverse faults followed by NW-SE normal oriented faults created during the Eocene age.

As the result of the strong inversion magnitude occurred toward northeast of the study area, it can be concluded that the area suffered from shortening and part of the Jurassic / Early Cretaceous normal faults are reactivated as reverse faults. Also the cap, the main rese rvoirs and the source rock sections brought to the surface and thus breached, as well any previous mature source rock becoming non-generative where the two dry wells Qatarani-1 and WD-38 are located. However, any less severe inversion structure in this case where WWER 2X, WWER-3 and WWER-4 wells are located (those wells are produce from upper Bahariya level) that remained buried by the post Eocene section will have a better chance or preserving the structure geometry and therefore top and lateral seal.

The WWER area is controlled by structure inversion which strongly affects the lateral, top seal, reactivate older faults and hydrocarbon trap in the area. The results of the study suggests that, an additional understanding of hydrocarbon generation and migration. Furthermore, studying the faults behavior in order to reduce uncertainty and risk before drilling

\section{Acknowledgements}

We wish to express our gratitude to the Egyptian General Petroleum Corporation (EGPC) and Abu Qir Petroleum Company (AQP) for their approval and permission to publish this work.

\section{References}

[1] G. Sestini, "Regional petroleum geology of the world, part II: Africa, America, Australia and Antarctica" (Vol. Beiträge zur regionalen Geologie der Erde, Band vol. 22, pp. 66-87, In Kulke, H. (Ed.), Gebrüder Bornträger Verlagsbuchhandlung, Stuttgart, 1995.

[2] N.J. Richardson, S.J. Rippington, R.W. Wilson, and C.E. Bond, “Industrial Structural Geology” Geological Society, London, Special Publication, vol. 421, pp. SP421-SP423, 2015.

[3] J.S. Young, "Geological structures and controls on half-graben inversion in the western Gunsan Basin", Yellow Sea. Korea Institute of Geoscience and Mineral Resources, Daejeon, pp. 305-350, South Korea, 2015.

[4] B. Freeman, D.J. Quinn, C.G. Dillon, M. Arnhild, and B. Jaarsma, "Predicting subseismic fracture density and orientation in the Gorm Field", Danish North Sea, in Richards, F.L., Richardson, N.J., Rippington, S.J., Wilson, R.W., and Bond, C.E., eds., Industrial Structural Geology: Principles, Techniques and Integration: Geological Society, London, Special Publication, vol. 421, pp. 421-429, 2015.

[5] N. Sultan, and M.A. Abdelhalim, "Tectonic framework of Northern Western Desert, Egypt and its effect on hydrocarbon accumulations" EGPC 9th, Cairo, vol. 2 pp. 1-23, 1988.

[6] A.R. Moustafa, "Mesozoic-Cenozoic Basin Evolution in the Northern Western Desert of Egypt" Geology of East Libya, vol. 3, pp. 29-46, 2008.

[7] Schlumberger, “Well Evaluation Conference”, Egypt, pp. 87, 1995.

[8] M. El Kammar, "Integrated geophysical study of East Bahariya and West wadi Elrayan, Western Desert, Egypt". Master Thesis (unpublished): Cairo University, 2014.

[9] S. Chopra, "What is seismic interpretation?" AAPG Explorer, 2013.

[10] T.G. Bevan, and A.R. Moustafa, "Regional Geology and Tectonics: Phanerozoic Rift Systems and Sedimentary Basins, Inverted rift-basins of northern Egypt", pp. 482-507, 2012.

[11] A. El Batal, et al, "Exploration precautions for the Hydrocarbon Accumulations of Jurassic and Early Cretaceous at the Area in between Abu-Gharadig and Gendi Basins". 8th March, 2016.

[12] M. Abd El Aziz, et al, “Impact of Basin Inversion on hydrocarbon Habitat in the Qarun Concession, Western Desert, Egypt”. In: Proc. 14th EGPC Petroleum Conference, V.I, pp. 139-155. 1998. 